Prepared in cooperation with the North Pacific Landscape Conservation Cooperative

\title{
Resource Manager Information Needs Regarding Hydrologic Regime Shifts for the North Pacific Landscape Conservation Cooperative
}

Open-File Report 2014-1178 



\section{Resource Manager Information Needs Regarding Hydrologic Regime Shifts for the North Pacific Landscape Conservation Cooperative}

By Andrea Woodward and Karen Jenni

Prepared in cooperation with the North Pacific Landscape Conservation Cooperative

Open-File Report 2014-1178

U.S. Department of the Interior

U.S. Geological Survey 


\title{
U.S. Department of the Interior \\ SALLY JEWELL, Secretary
}

\section{U.S. Geological Survey \\ Suzette M. Kimball, Acting Director}

U.S. Geological Survey, Reston, Virginia: 2014

For more information on the USGS-the Federal source for science about the Earth,

its natural and living resources, natural hazards, and the environment-visit

http://www.usgs.gov or call 1-888-ASK-USGS

For an overview of USGS information products, including maps, imagery, and publications, visit $h$ ttp://www.usgs.gov/pubprod

To order this and other USGS information products, visit http://store.usgs.gov

\author{
Suggested citation: \\ Woodward, Andrea, and Jenni, Karen, 2014, Resource manager information needs regarding hydrologic regime shifts \\ for the North Pacific Landscape Conservation Cooperative: U.S. Geological Survey Open-File Report 2014-1178, \\ 28 p., http://dx.doi.org/10.3133/ofr20141178. \\ ISSN 2331-1258 (online)
}

Any use of trade, firm, or product names is for descriptive purposes only and does not imply endorsement by the U.S. Government.

Although this information product, for the most part, is in the public domain, it also may contain copyrighted materials as noted in the text. Permission to reproduce copyrighted items must be secured from the copyright owner. 


\section{Contents}

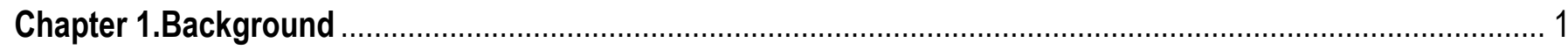

Description and Purpose of Landscape Conservation Cooperatives ................................................................. 1

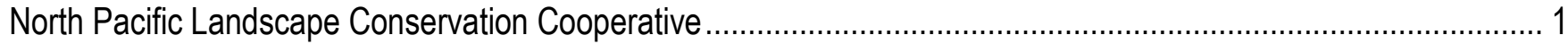

Identifying Information Needs of Resource Managers ............................................................................... 3

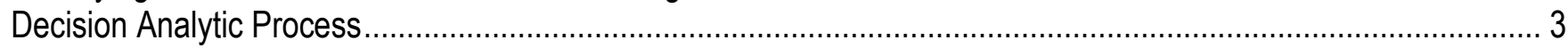

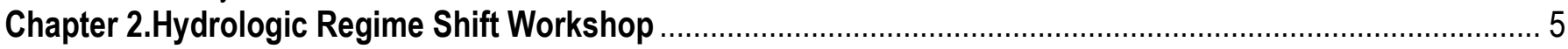

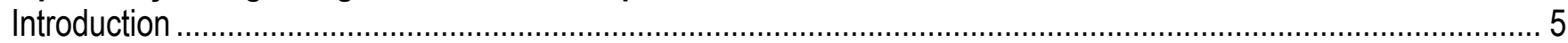

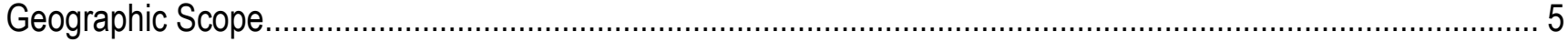

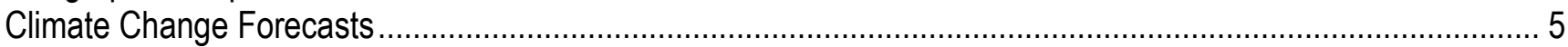

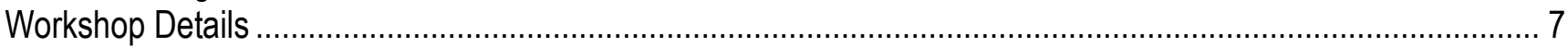

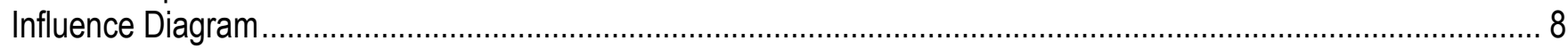

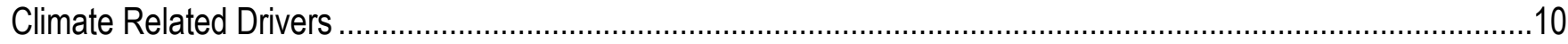

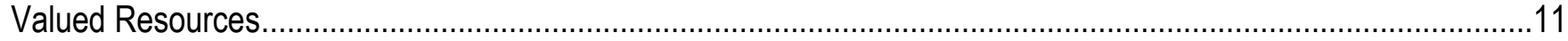

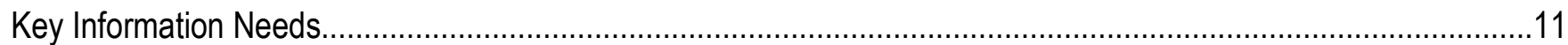

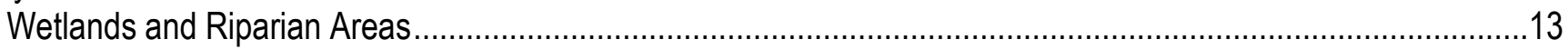

Fisheries and Aquatic Habitats.........................................................................................................

Infrastructure Planning, Agriculture, Human Habitats and Cultural Resources .................................................17

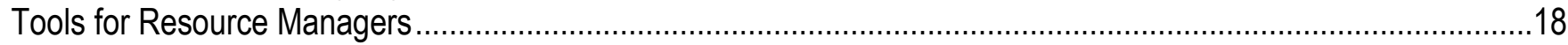

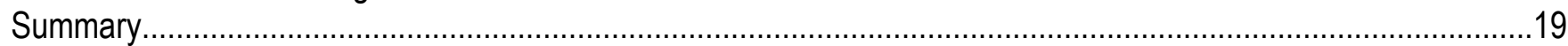

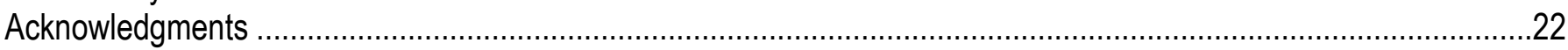

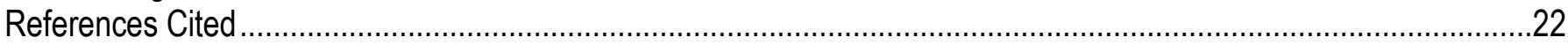

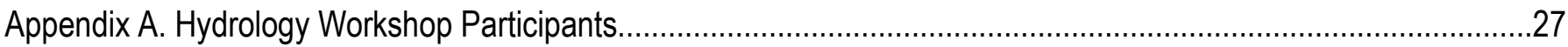

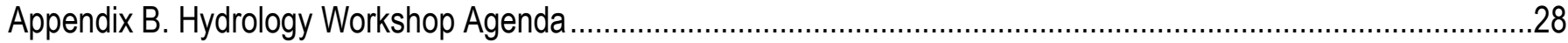

\section{Figures}

Figure 1.1 Elements of decisions made by resource managers as represented in Analytica $₫$ software ….................. 4

Figure 2.1 Predicted changes in abundance and distribution of rain-dominated, transient, and snow-dominated watersheds in the focal region (Tohver and others, 2014) .......................................................................... 6

Figure 2.2 Example hydrograph from the Nisqually River, Washington illustrating predicted changes due to climate change

Figure 2.3 Influence diagram illustrating a conceptual model of the relationships among valued natural and cultural resources potentially affected by hydrologic regime shifts and the management decision, climate-related factors, and related natural process that may affect those resources and the ability to achieve the related management objectives.

Figure 2.4 Identified key information needs to support decision-making related to protection and management of wetlands and riparian areas subject of changing hydrologic regimes

Figure 2.5 Identified key information needs to support decision-making related to protection and management of aquatic habitats and fisheries that are subject of changing hydrologic regimes...

Figure 2.6 Identified key information needs to support decision-making related to protection and management of infrastructure that is subject of changing hydrologic regimes

Figure 2.7 Identified key information needs to support conservation and sustainable natural resource management decision about resources affected by climate-induced changes in hydrologic regimes 


\section{Tables}

Table 2.1 Valued natural and cultural resources potentially affected by hydrologic regime shifts and associated management objectives, as identified by workshop participants.

Table 2.2 Data and tools that would be useful to meet information needs.

\section{Conversion Factors and Datum}

\section{Conversion Factors}

SI to Inch/Pound

\begin{tabular}{rcrl}
\hline Multiply & By & To obtain \\
\hline & Area & \\
\hline square kilometer $\left(\mathrm{km}^{2}\right)$ & 247.1 & acre & \\
\hline
\end{tabular}

Temperature in degrees Celsius $\left({ }^{\circ} \mathrm{C}\right)$ may be converted to degrees Fahrenheit $\left({ }^{\circ} \mathrm{F}\right)$ as follows:

${ }^{\circ} \mathrm{F}=\left(1.8 x^{\circ} \mathrm{C}\right)+32$. 


\title{
Resource Manager Information Needs Regarding Hydrologic Regime Shifts for the North Pacific Landscape Conservation Cooperative
}

\author{
By Andrea Woodward ${ }^{1}$ and Karen Jenni²
}

\section{Chapter 1. Background}

\section{Description and Purpose of Landscape Conservation Cooperatives}

Landscape Conservation Cooperatives (LCCs) are a network of 22 public-private partnerships, defined by ecoregion, that share and provide science to ensure the sustainability of land, water, wildlife, and cultural resources in North America. LCCs were established by the U.S. Department of the Interior (DOI) in recognition of the fact that response to climate change must be coordinated on a landscape-level basis because important resources, ecosystem processes, and resource management challenges extend beyond most of the boundaries considered in current natural resource management. Traditional boundaries include national wildlife refuges, Bureau of Land Management lands, national parks, and even international boundaries, but many ecological and natural resources cross all these boundaries. Therefore, DOI agencies must work with other Federal, State, Tribal (U.S. indigenous peoples), First Nation (Canadian indigenous peoples), and local governments, as well as private landowners, to develop landscape-level strategies for understanding and responding to climate change.

\section{North Pacific Landscape Conservation Cooperative}

The North Pacific LCC (NPLCC) covers the range of the Pacific coastal temperate rainforest, including an area of $528,360 \mathrm{~km}^{2}$ spanning 22 degrees of latitude from the Kenai Peninsula, Alaska, to Bodega Bay, California. The coverage area includes parts of four States, two Canadian provinces, and more than 100 Tribes and First Nation language groups. It extends from alpine areas at the crest of coastal mountains across subalpine, montane, and lowland forests to the nearshore marine environment. This wide range of latitudes and elevation zones; terrestrial, freshwater, and marine habitats; and complex jurisdictional boundaries hosts a diversity of natural resources and their corresponding management issues are equally diverse.

\footnotetext{
${ }^{1}$ U.S. Geological Survey.

${ }^{2}$ Insight Decisions, LLC.
} 
The specific mission of the NPLCC is to promote "development, coordination, and dissemination of science to inform landscape level conservation and sustainable resource management in the face of a changing climate and related stressors" (North Pacific Landscape Conservation Cooperative, undated). The strategy for identifying, prioritizing, and addressing science needs is the responsibility of the Science and Traditional Ecological Knowledge (S-TEK) Subcommittee, which established the following guiding principles in the NPLCC Strategy for Science and Traditional Ecological Knowledge, 2013-16 (S-TEK Strategy; Jenni and others, 2012):

- Focus on helping managers understand the availability and effectiveness of adaptation and mitigation response actions;

- Focus on facilitating coordination, collaboration, and capacity building, and on developing or assisting with tools to assist decision-makers;

- Identify and promote opportunities to use Traditional Ecological Knowledge (TEK) to inform partner and stakeholder decisions;

- Promote and facilitate understanding of the connections and interactions between ecosystems.

These principles emphasize the importance of conducting activities that are immediately relevant to resource managers.

In addition to guiding principles, the S-TEK committee also identified five priority topics to be addressed in the first 4-year strategic plan:

1. Effects of hydrologic regime shifts on rivers, streams, and riparian corridors;

2. Effects of change in air temperature and precipitation on forests;

3. Effects of changes in sea levels and storms on marine shorelines, the nearshore, and estuaries;

4. Effects of the changes in the hydrologic regime on anadromous fish; and

5. Invasive species, diseases, pests, and their effects on biological communities. 


\section{Identifying Information Needs of Resource Managers}

As evidenced by the S-TEK Strategy guiding principles (Jenni and others, 2012), identifying and responding to the needs of resource managers is key to the success of the NPLCC. To help achieve this goal of the NPLCC, the U.S. Geological Survey (USGS) has organized several workshops with resource managers and resource scientists to identify management information needs relevant to the priority topics identified in the S-TEK Strategy (Woodward and others, 2014). Here, we detail the results from a first workshop to address the effects of changes in hydrologic regime on rivers, streams, and riparian corridors. The workshop focused on a subset of the full NPLCC geography (see section, "Geographic Scope") and was structured to answer the following questions:

- What are the valued resources and services that may be affected by hydrologic regime changes in the region?

- What are the management goals for those resources?

- How is climate change anticipated to affect valued resources and goals?

- What adaptation strategies may managers use in response to anticipated changes in resources due to climate-related hydrologic change?

- What information is needed to inform and use management responses?

The workshop was conducted in 1 day and was professionally facilitated using a decision analytic process (Keefer and others, 2004).

\section{Decision Analytic Process}

Decision analysis (DA) is a framework and a process used to formally structure the decision-making process, and consists of relevant philosophy, theory, methodology, and professional practice (Keefer and others, 2004). Decision analysis includes procedures, methods, and tools to help decision makers identify, clearly represent, and formally assess important aspects of a decision in order to recommend a course of action.

The influence diagram is an important tool often used during decision analysis to structure and to communicate the various components of a decision situation. Often used as the first step towards analyzing decision options, the influence diagram is a simple visual representation used to identify and to display the essential elements of a decision problem (Howard and Matheson, 2005; Pearl, 2005). Elements include (1) objectives (what people would like to achieve in the particular situation being evaluated), (2) types of decisions and decision points (what actions can be taken to try to bring about more desirable outcomes), and (3) uncertainties (factors, events, and processes that affect outcomes but that are outside the control of decision-makers), and the relationships between all three elements. The influence diagram is a high-level conceptual model from which more detailed quantitative models can be built. We did not intend to develop quantitative models; rather, we used influence diagrams to describe the decision context, management actions, and desired outcomes for the group of natural resources addressed during each workshop as a means of conceptualizing the issues and creating consensus. 
Influence diagrams were created using Analytica ${ }^{\circledR}$ software developed by Lumina Decision Systems ${ }^{\circledR}$. In this format (fig. 1.1), rectangles denote decision points (variables or factors that the decision-maker can modify), ovals denote uncertainties (variables or factors about which information is incomplete and that cannot be controlled directly), hexagons denote objectives or measures of satisfaction and what managers want to maximize, rounded rectangles denote general variables whose values are determined by the quantities on which they depend, and arrows denote influences of one variable on another. The influence indicated by arrows is not necessarily causal or related to a material flow; rather, the arrow denotes when knowledge about one variable is relevant to determining the value of another variable.

Management actions

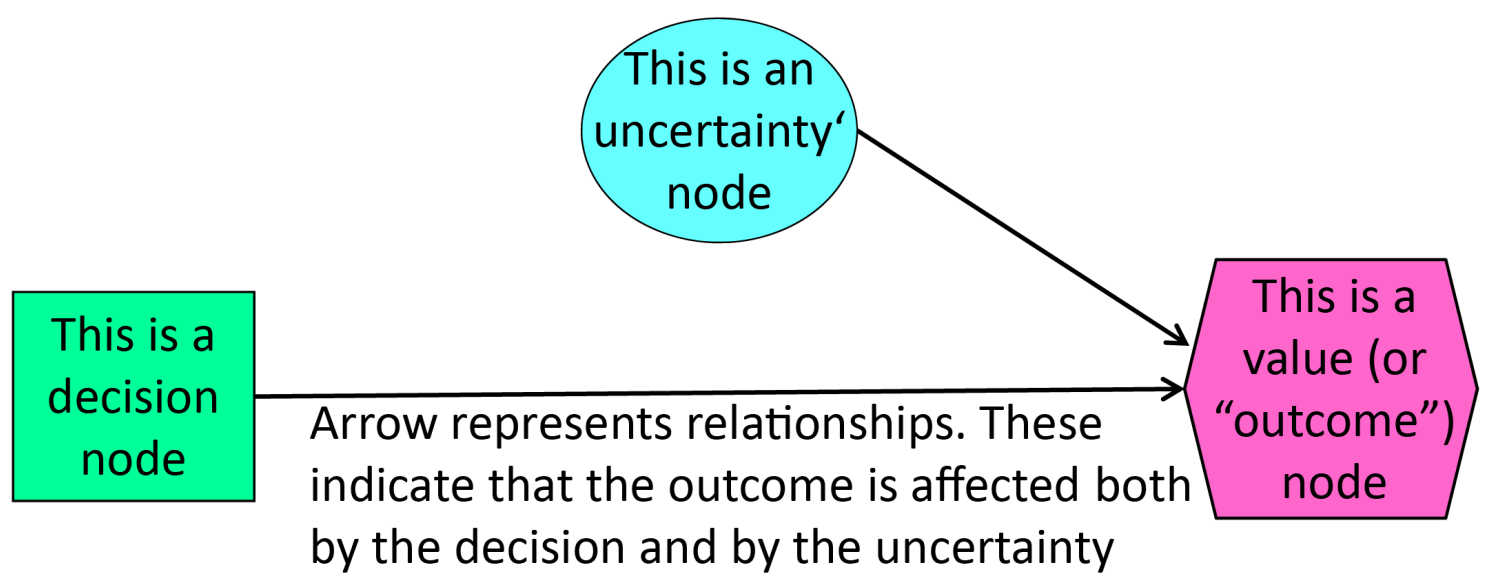

\section{Information needs Management goals} by the decision and by the uncertainty

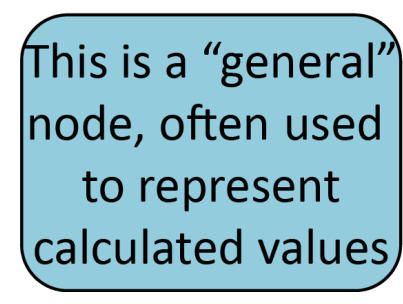

. 


\section{Chapter 2. Hydrologic Regime Shift Workshop}

\section{Introduction}

\section{Geographic Scope}

The NPLCC encompasses a very diverse geography along the coast from Alaska to northern California. Previous workshops have focused on identifying topic-related information needs that are shared across the full geography (Woodward and others, 2014). For this topic, the hydrologic regimes and projected climate-related changes in those regimes are sufficiently different across the region that management-related information needs might also be very different. Consequently, we focused the workshop on one of four subregions of the NPLCC defined based on climate, geology, and the resulting hydrologic regime. The workshop described in this chapter spans the NPLCC from mid-Washington to the northern end of the Klamath Mountains in southern Oregon. This subregion is typified by volcanic bedrock (basalt and andesite) in the Cascade Mountains and a diversity of substrates including sandstone and siltstone at low elevations (Franklin and Dyrness, 1973; Whitehead, 1994), snowpack as an important driver of water availability and spring runoff (Barnett and others, 2005; Littell and others, 2010), and the presence of valley (rather than tidewater) glaciers.

\section{Climate Change Forecasts}

Climate change forecasts for the focal area were presented as a webinar prior to the meeting. Participants could join the meeting in person or watch a recording at another time. Presenters included Ingrid Tohver (University of Washington Climate Impacts Group), who talked about hydrologic response to climate change, and Dan Isaak (U.S. Department of Agriculture, Forest Service Rocky Mountain Research Station), who talked about predicted changes in stream temperature.

With average annual air temperature projected to increase as much as $4.5^{\circ} \mathrm{C}$ by $2071-$ 2100 relative to 1950-99 (Abatzoglou and others, 2013), the key climate effect on hydrology in the Pacific Northwest is predicted to be less snow. The effects will be most noticeable for midelevation basins, which are transitional between the rain-dominated low-elevation basins and snow-dominated basins at high elevations. These basins currently store 10-40 percent of winter precipitation as snow and release it as melt water later in the year (Hamlet and others, 2013). As transient, and eventually even snow-dominated, basins transition to rain-dominated basins (fig. 2.1; Chang and others, 2012; Tohver and others, 2014), hydrologic consequences will include earlier and higher peak spring snowmelt and flow, lower summer streamflow (fig. 2.2), and increased winter flood risk (Hamlet and others, 2013). 


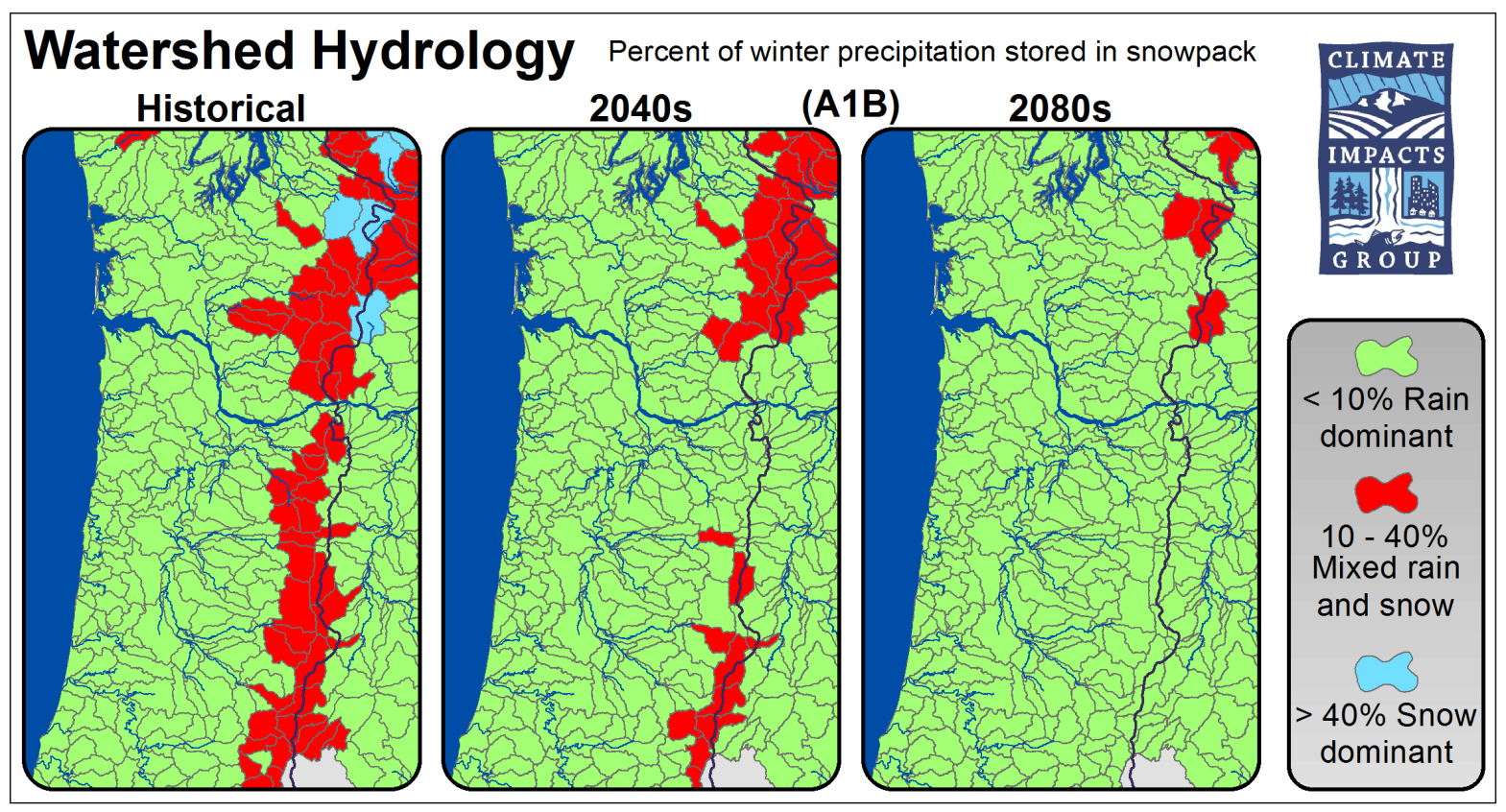

Figure 2.1 Predicted changes in abundance and distribution of rain-dominated, transient, and snowdominated watersheds in the focal region (Tohver and others, 2014).

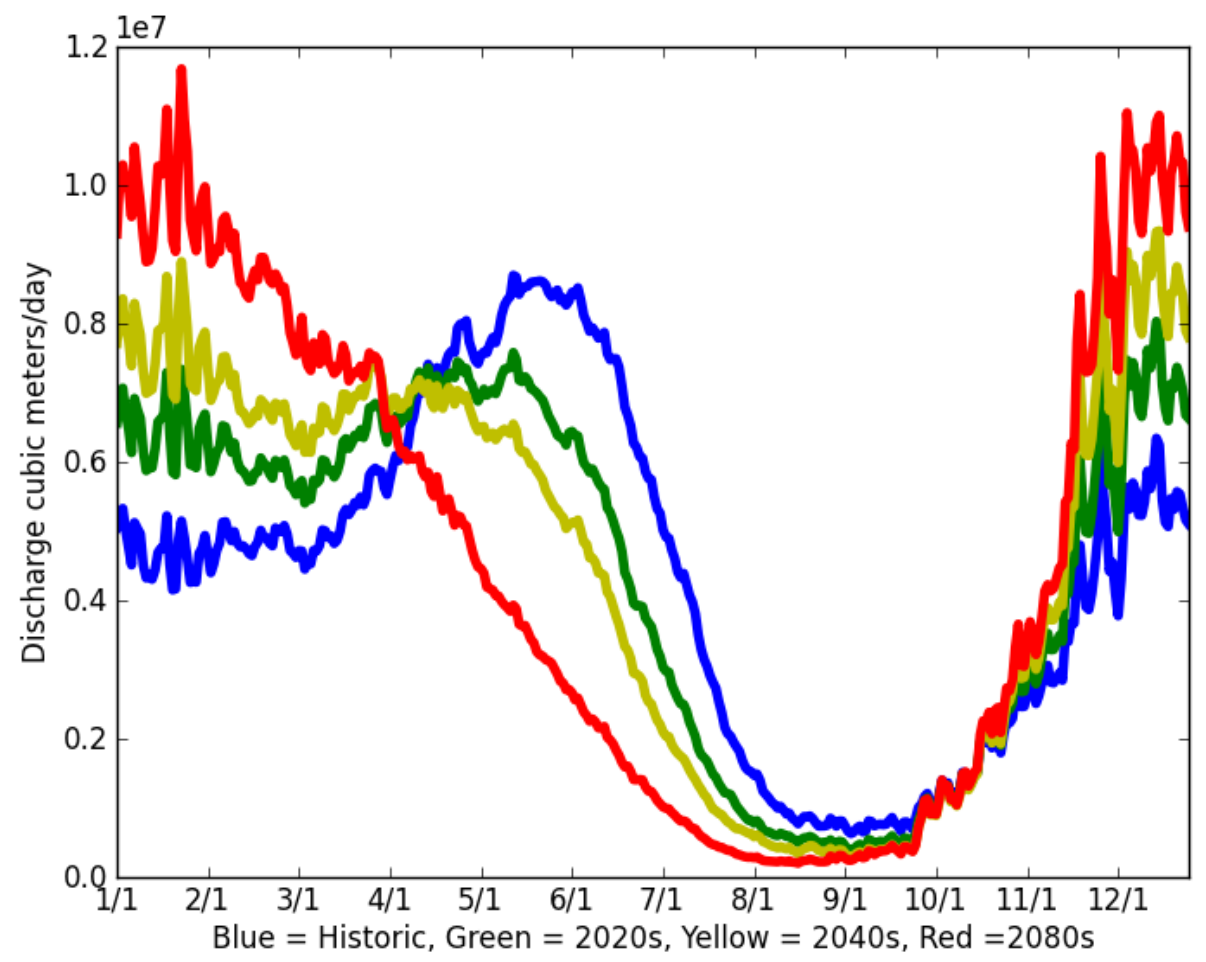

Figure 2.2 Example hydrograph from the Nisqually River, Washington, showing predicted changes due to climate change. 
Increased air temperature also will affect stream temperature and, therefore, fish habitat. Although stream temperature is predicted to warm less rapidly than air temperature (Isaak and others, 2012), predicted changes are for a $0.30-0.45^{\circ} \mathrm{C}$ increase per decade during summer at unregulated sites based on analysis of 30 -year records of stream temperature trends from sites including tributaries to the Columbia River and projected climate change (Mantua and others, 2010; Isaak and others, 2012). Several studies indicate that changes in stream temperature will affect fish distribution (Rich, 2003; Comte and Grenouillet, 2013; Eby and others, 2014).

Notably, the short time series of information and the variety of statistical models used to project change lead to a high degree of variability and uncertainty among these predictions (Arismendi and others, in press). The influences of local factors such as riparian canopy shading and land and water uses are sometimes more important than warming air on water temperature (Arismendi and others, 2012; Diabat and others, 2012).

Both presenters identified datasets that are available or are being developed to describe predicted changes in flow regime and stream temperature for the focal area. These include the Columbia River Basins Project (http://warm.atmos.washington.edu/2860/), the Riverscape Analysis Project from the University of Montana (http://rap.ntsg.umt.edu/), and the NorWeST stream temperature database (http://www.fs.fed.us/rm/boise/AWAE/projects/NorWeST.html). Some fine-scale projections of flood and low-flow magnitudes are available for a few areas from the University of Washington (file onf-q100 at ftp://ftp.hydro.washington.edu/pub/hamleaf/).

\section{Workshop Details}

The workshop to identify the information needs of resource managers regarding changes in hydrologic regime was held in Portland, Oregon, on January 23, 2014. Fifteen people attended, representing one or more of the following agencies and Tribes (see appendix A for a list of participants and affiliations):

- Columbia River Intertribal Fish Commission

- National Oceanic and Atmospheric Administration National Marine Fisheries Service

- Natural Resources Conservation Service

- North Pacific Landscape Conservation Cooperative

- Oregon Climate Change Research Institute

- Oregon Metro

- Oregon State University

- Portland State University

- U.S. Army Corps of Engineers

- U.S. Fish and Wildlife Service, Oregon Fish and Wildlife Office

- U.S. Fish and Wildlife Service, Pacific Region Water Resources Branch

- U.S. Fish and Wildlife Service, Washington Fish and Wildlife Office

- U.S. Forest Service, Pacific Northwest Research Station

- U.S. Forest Service, Region 6

- U.S. Geological Survey, Northwest Climate Science Center

- Washington State Department of Ecology

- Washington Department of Fish and Wildlife

- Washington State Department of Transportation 
The workshop was organized by Andrea Woodward and facilitated by Karen Jenni (Insight Decisions) using the principles of decision analysis (Keefer and others, 2004) described in chapter 1 of this report. The overarching goal was to determine what information managers need in order to address the consequences of climate-change given management goals, high-priority resources, and available management tools. The workshop agenda is shown in appendix B.

\section{Influence Diagram}

A first-order conceptual model in the form of an influence diagram was developed early during the workshop. The influence diagram provided structure to a wide-ranging discussion, and highlighted areas for more detailed discussion and identification of potential information needs. It was used to draw attention back to the larger context during these detailed discussions so that identified information needs could always be connected to the decisions that information would be used to support, and to how that information would enable decision-makers to better achieve their management objectives for the valued resources. It is not, and was not intended to be, a definitive model of hydrologic regime shifts and all the potential impacts of those shifts. Rather, the goal of conceptual model development was to identify and clarify the group's consensus regarding relationships among:

- Climate-related drivers of changes in hydrologic regimes (left side of fig. 2.3);

- Valued natural and cultural resources that are potentially affected by changes in the hydrologic regime in the region of the NPLCC being considered, and the desired outcomes or management objectives for those valued resources (right side of fig. 2.3);

- Additional factors, conditions, and processes that comprise the most relevant pathways through which climate changes and hydrologic regime changes may affect the valued natural resources;

- Decisions or actions that conservation and sustainable natural resource managers can make to affect the valued resources (bottom left of fig. 2.3). 


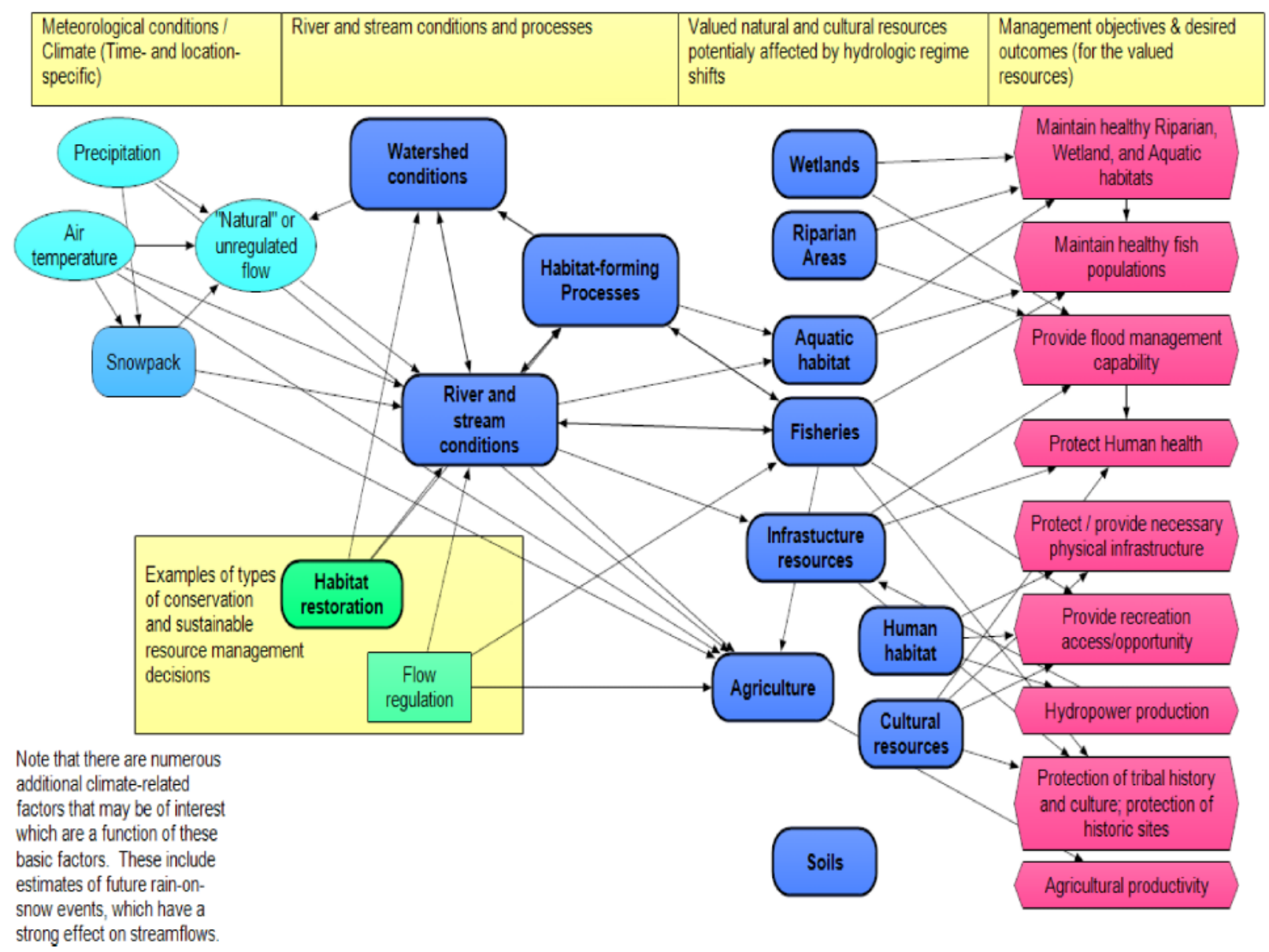

Figure 2.3 Influence diagram showing a conceptual model of the relationships among valued natural and cultural resources potentially affected by hydrologic regime shifts and the management decisions, climaterelated factors, and related natural processes that may affect those resources and the ability to achieve the related management objectives. 


\section{Climate Related Drivers}

The group described river and stream conditions as fundamental to the status of valued resources and as the scale at which managers primarily take action. Climate change will affect conditions in rivers and streams directly and indirectly by affecting watersheds, and habitatforming processes. The emphasis during the workshop discussion of drivers of changes was on flood events and conditions leading to them, and rain-on-snow events in particular (Loukas and others, 2000; McCabe and others, 2007). Factors affecting flood intensity due to rain-on-snow events potentially include the frequency of cold conditions, which result in snow, that are followed by 'atmospheric river' events, which bring warm air and heavy precipitation (Neiman and others, 2008; Leung and Qian, 2009). Changes in watershed area contributing to runoff due to shifts in rain-dominated, transient, and snow-dominated basins (Hamlet and others, 2013) also were discussed. The potential for atmospheric river events to differ from frontal storms in destructiveness was brought up, but dismissed as not an important distinction (Gordon Grant, Oregon State University, oral commun., 2014).

Other important factors related to flooding were mentioned. Specifically, the potential for rain on bare ground to also cause severe flooding should not be overlooked, and can result from fires or other disturbances (Ziemer, 1998; Miller and others, 2003; Tague and Grant, 2004; Grant and others, 2008). Also, floods occur on a continuum of severity, and some level of flooding is beneficial. Besides creating and renewing aquatic habitat (Waples and others, 2009), floods may be less tolerated by non-native species compared with natives such that non-native species may be constrained by flood events (Marchetti and Moyle, 2001). Finally, the timing as well as severity of floods is relevant to understanding the effects of those floods (Stewart and others, 2005), including timing relative to periods of increased vulnerability represented by the presence of migratory species.

It also was noted that while the focus of climate change projections is often on changes in flood dynamics, in fact droughts may be more dangerous to fish and aquatic species, especially in systems where flows are managed for irrigation storage, which have a greater capacity to absorb high flows than to mitigate for low flows (Miles and others, 2000; Mote and others, 2003; Palmer and others, 2008). Droughts are longer lasting than floods and may exceed the capacity of species to cope. Moreover, species in the Pacific Northwest are better adapted to surviving floods (Reeves, and others, 1995; Waples and others, 2008) than droughts, and therefore may have more tolerance for increased flooding, although justification for this statement is weak. Workshop participants suggested that it might be worthwhile to consider which species will be affected by changing hydrology in the next 5-10 years, rather than the next 30 , because effects of drought may be apparent sooner than effects of flood events.

Participants expressed that while something is known about the linkage between meteorology and watershed condition, and between stream condition and status of valued resources, not enough is known about the intermediate relationships among watershed conditions and habitat-forming processes, which create river and stream conditions (see fig. 2.3). The most important elements of river condition were identified as water, sediment, and organic material (primarily vegetation). Important habitat forming processes include scour, mobilization, transport and deposition of sediment as well as recruitment, deposition and retention of large wood. The scale at which least is known - the river and stream scale - is also the scale at which managers most often can take action. 


\section{Valued Resources}

As shown in figure 2.3, participants identified nine types of valued natural and cultural resources associated with rivers, streams, and riparian habitats for which hydrologic regime shifts were considered to pose a potential stress or management challenge. For each of these valued resources, the workshop participants also identified one or more management "objectives." The term "objectives" is used to differentiate these relatively general statements about what managers are trying to achieve with respect to the resources from the much more detailed and specific management "goals" that typically are associated with a particular project or specific resource. For example, a management objective for Fisheries might be to "maintain healthy fish populations," whereas a management goal might be to increase a given fish stock by a specific amount. The identified valued natural and cultural resources, and the management objectives for each are shown in table 2.1. Most of the valued resources were affected by climate through stream and river condition, but agriculture was identified as also being directly responsive to climate.

\section{Key Information Needs}

For purposes of workshop discussions, eight of the initially identified valued resources were grouped into three groups based on whether it was felt that the information needed to support decision-making about those resources would be similar (soils were not considered at this point):

- Wetlands and riparian areas, habitats at the interface between terrestrial habitats and rivers and streams. The most significant stresses will likely come from floods or sustained low flows.

- Aquatic habitats and fisheries, focusing on the biotic communities directly dependent on the flow regime and quality of water in rivers and streams.

- Infrastructure, agriculture, cultural resources and human habitat, all resources where the decision-making focus is on maintaining services of direct value and importance to humans.

For each of these three groups, workshop participants identified a set of key decisionrelevant information needs. In doing so, they first identified a set of management decisions or management questions related to the resources, then specified what information they would ideally have in order to make those decisions. The initial set of information needs usually led to the identification of additional information that would help meet the first information need, and so on.

The information structures diagrammed in figures 2.4-2.6 are meant to illustrate how information needs relate to one another, how information will be used, and an indication of the sequence in which information is needed. In this way, we attempted to limit the identification of information needs to those with the highest priority and greatest applicability. 
Table 2.1. Valued natural and cultural resources potentially affected by hydrologic regime shifts and associated management objectives, as identified by workshop participants.

\begin{tabular}{|c|c|}
\hline Valued natural and / or cultural resources & Management objective(s) \\
\hline Wetlands & $\begin{array}{l}\text { - Maintain healthy wetland habitats-defined by appropriate water } \\
\text { levels in particular seasons and maintenance of } \\
\text { groundwater/surface- water interactions } \\
\text { - Maintain / provide flood management capability }\end{array}$ \\
\hline Riparian areas & $\begin{array}{l}\text { - Maintain healthy riparian habitats, including shade and source for } \\
\text { large wood recruitment } \\
\text { - Maintain / provide flood management capability }\end{array}$ \\
\hline Aquatic habitat & $\begin{array}{l}\text { - Maintain healthy aquatic habitats } \\
\text { - Maintain healthy fish populations }\end{array}$ \\
\hline Fisheries & $\begin{array}{l}\text { - Maintain healthy fish populations } \\
\text { - Protect Tribal history and culture } \\
\text { - Provide recreation access and opportunities } \\
\end{array}$ \\
\hline Infrastructure resources & $\begin{array}{l}\text { - Protect human health (for example, through flood protection and } \\
\text { maintenance of evacuation routes) } \\
\text { - Minimize economic losses (for example, due to floods) } \\
\text { - Provide recreation access and opportunities } \\
\text { - } \text { Maintain transportation corridors (including evacuation routes) } \\
\text { - Protect/provide appropriate and necessary infrastructure (for } \\
\text { example roads, bridges, waste water treatment, hazardous waste } \\
\text { containment) } \\
\text { - Protect historical infrastructure, which may include dams and } \\
\text { national park service structures } \\
\text { - Hydropower production }\end{array}$ \\
\hline Agriculture & $\begin{array}{l}\text { - Maintain / improve agricultural productivity } \\
\text { - Address water availability, both physically through flow regulation } \\
\text { and legally through allocation of water rights } \\
\text { - Prevent water and insect-borne crop diseases }\end{array}$ \\
\hline Human habitat & $\begin{array}{l}\text { Protect human health (for example, through flood protection, } \\
\text { provision of water for human uses, prevention of disease spread) } \\
\text { Provide recreational access and opportunities }\end{array}$ \\
\hline Cultural resources & $\begin{array}{l}\text { - Protect Tribal history and culture } \\
\text { - Protect historical sites } \\
\text { - Maintain / provide aesthetic resources }\end{array}$ \\
\hline Soils & $\begin{array}{l}\text { The issue of soils as a valued natural resource potentially affected } \\
\text { by hydrologic regime changes came up relatively late in the } \\
\text { workshop and was not the focus of detailed discussion. However, it } \\
\text { mainly related to the importance of soils in determining agricultural } \\
\text { practices and acknowledgment that soils are only regulated when } \\
\text { they cause turbidity and pollution in water. }\end{array}$ \\
\hline
\end{tabular}




\section{Wetlands and Riparian Areas}

The key information needs identified for wetlands and riparian areas is shown in figure 2.4. The figure was created moving from right to left-starting with the management decisions that must be made in order to protect or manage the valued resources of wetland and riparian areas on the far right and then working "backwards," identifying the most directly relevant information that would be used to support those decisions first and then additional information that might be necessary to create the primary information needed. In developing a plan to provide the key information, the figure might be read from left to right - the information on the far left supports the development of the information in the middle of the diagram, which directly supports the decisions.

For this set of valued resources, participants asserted that the primary management decisions would be regarding water flow regulation and dam operations in regulated flow systems, and decisions about land use and water management in unregulated flow systems. Water management actions in unregulated systems include such activities as well use and irrigation withdrawals. Most research to date (2014) has focused on predicting effects of climate change on flow and stream temperature (Kundzewicz and others, 2008). The key new information that workshop participants identified as necessary to support these decisions is an accurate understanding of how much of the climate-driven changes in hydrology can be addressed through each possible management action. Thus, there is a need to quantify the ratio of the amount of climate driven changes to the amount of change that can be addressed through management. We know that in regulated flow systems (regulated physically and legally), the capacity to adjust flow far exceeds the potential effect of climate change on flow, although doing so may reduce the capacity of the river to meet needs for energy, recreation, and irrigation (Hamlet and Lettenmaier, 1999; Palmer and others, 2008). Given this capacity to adjust the amount and timing of flows, there is substantial ability to mitigate climate-driven changes in regulated systems. Less is known about the capacity to adjust flow in unregulated flow systems by adjusting land and water management, and about how that compares with the potential effect of climate change on flow. We also lack this information regarding the capacity of various management tools to affect stream temperature relative to potential changes due to climate change. Information that would be necessary to develop an understanding of that relationship includes predicted streamflows, specifically intensity, duration, and Intensity-Frequency-Curves (IDF curves; Durrans, 2010). It also includes an assessment of the effectiveness of available management tools in both regulated flow and unregulated flow systems. 


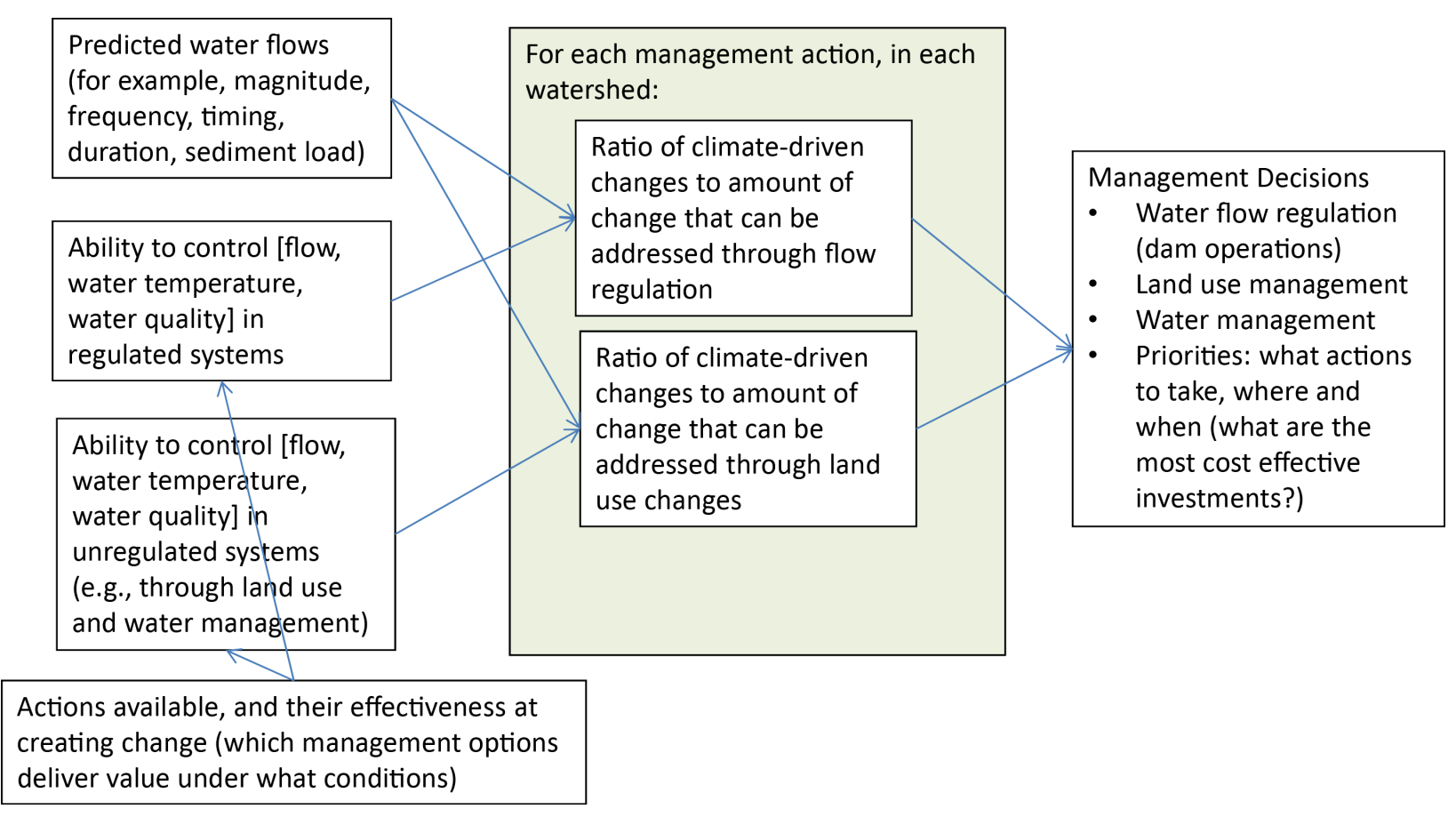

Figure 2.4 Identified key information needs to support decision-making related to protection and management of wetlands and riparian areas subject of changing hydrologic regimes.

The workgroup emphasized that, because management resources are limited, conservation and sustainable natural resource management entities must set priorities, deciding what management actions to take, and where and when to take those actions. Ideally, priorities would be set based on monetizing costs and benefits of management actions. A first step toward this involves improving our understanding of the benefits of various management actions such as wetlands restoration, floodplain reconnection, and side-channel enhancement on stream temperature, sediment, and other water quality measures. Many of these actions are being done today to support biodiversity goals, but could also have substantial benefits for water quality, especially temperature. An example from Oregon is Washington County's Clean Water Services, which is implementing a large shade program to maintain their permit for waste water discharge into the Tualatin River (Jonathan Soll, Oregon Metro, written commun., 2014). If they, or other utilities with a mitigation need, were able to invest in additional activities with confidence, the results could be mitigation for warming streams as well as improved aquatic system function and biodiversity. However, the required confidence in the effectiveness of additional mitigation activities requires better documentation of when such actions provide real benefit and better quantification of the amount of benefit. 


\section{Fisheries and Aquatic Habitats}

The key information needs identified for aquatic habitats and fisheries is shown in figure 2.5. For this set of valued resources, participants identified the primary management decisions as decisions regarding where to implement habitat protection and/or restoration activities. Filling the need for information requires identifying watersheds and reaches within watersheds where protection or restoration activities are likely to be successful. Other decisions regard choosing specific actions to undertake, but participants indicated that there is less uncertainty about what to do than where to do it.

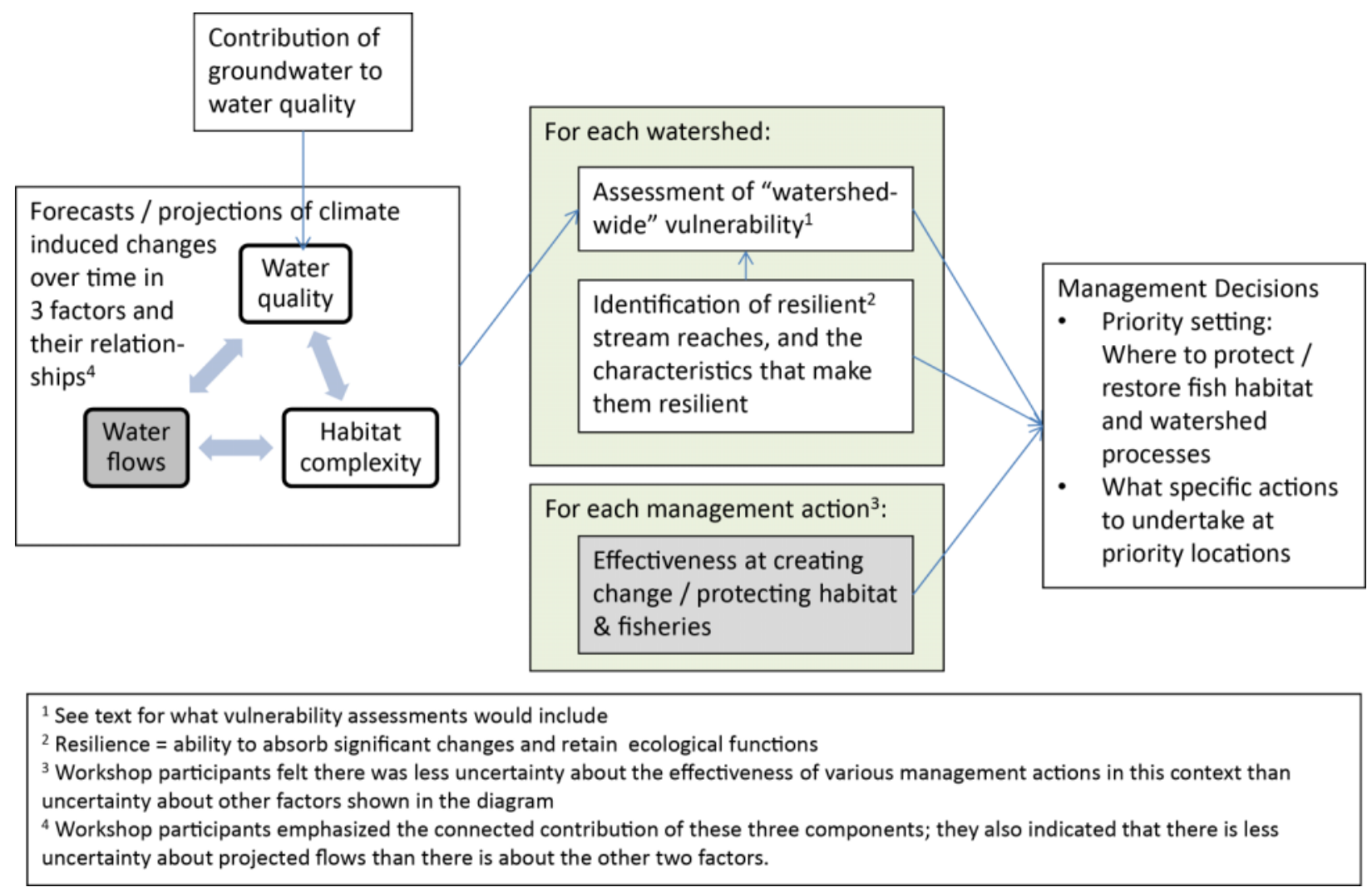

Figure 2.5 Identified key information needs to support decision-making related to protection and management of aquatic habitats and fisheries that are subject of changing hydrologic regimes. 
Therefore, participants identified vulnerability assessments of watersheds and identification of resilient stream reaches as the most important information needed to support management decisions. To date (2014), resource managers have planned activities based on watershed assessments, which do not consider changing climate (Beechie and others, 2003; Beechie and others, 2013). Moving forward, climate change vulnerability assessments must become an important input to management decisions regarding fisheries and habitat protection and restoration; a framework for including vulnerability assessments as part of watershed assessments is needed. Some modules of watershed assessments likely can be easily modified to address climate vulnerability. Additionally, a tool is required at the reach scale to identify resilient reaches where resilience is defined as the ability to absorb substantial change in input factors without substantial change in ecosystem function. Important elements to evaluate may include upstream and downstream connectivity, floodplain connectivity, vegetation characteristics, geology, food web processes, and others (Roni and others, 2002; Bellmore and others, 2013). These might be assessed by adapting the properly functioning condition (PFC) protocol used for riparian and wetland areas (Bureau of Land Management, 1998).

Developing assessment tools at both the watershed and reach scales depends on understanding that habitat quality is a function of flow regime, water quality (including temperature), and habitat complexity. At present (2014), we can make dynamic projections for flow and water quality, particularly water temperature (Isaak and others, 2012), to describe changes due to climate change scenarios over time (Mote and others, 2003; Littell and others, 2010). However, habitat complexity has only been described statically using habitat surveys. Recently, a qualitative stream evolution model (Cluer and Thorne, 2014) has been developed to describe the evolution of habitat over time; workshop participants felt that quantification of that model would make it more useful. Other factors in need of deeper understanding and predictive capability include the role of groundwater in providing thermal refugia (Tague and others, 2008) and the relationship of climate change to geology and consequent sediment load. Finally, although transient and snow-dominated basins have been identified as most sensitive to climate change (Hamlet and others, 2013), there may be significant changes happening in rain-dominated basins as well (Chang and Jong, 2010). Examples include changes in native species compositions and invasions of nonnatives that are linked to climate change (Lawrence and others, 2014). 


\section{Infrastructure Planning, Agriculture, Human Habitats and Cultural Resources}

Although these four types of valued resources were identified as having some commonalities, workshop participants focused primarily on infrastructure when identifying the potential information needs related to this set of resources. Although the other topics were discussed, there was insufficient time to develop diagrams for them. The key information needs identified for infrastructure resources is shown in figure 2.6.

For this set of valued resources, participants identified the primary management decisions as decisions about where and how to protect and maintain existing infrastructure, and about the design, location, and emplacement timing for new infrastructure. As with the other resources, the need of management entities to set priorities about where, when, and what actions to pursue also was identified as important. Priorities might be set based on vulnerability assessments, which categorize structures as 'fixable,' 'resilient therefore worthy of protection,' and 'cannot be fixed so do not waste money.' Participants emphasized the need for improved, detailed projections of water flows, especially flood-level flows. In particular, they identified the need for fine-scale information, to enable better understanding of local scale vulnerability and potential adaptation actions. Specifically mentioned was the importance of creating improved predictive tools (for example, regression equations and IDF curves) that account for non-stationarity in the frequency and severity of high-flow events (Merz and others, 2011; Yousef and Ouarda, 2013). Work on this is being done for the focal geographic area by researchers at Oregon State University and the U.S. Department of Agriculture Forest Service (Gordon Grant, Oregon State University/Forest

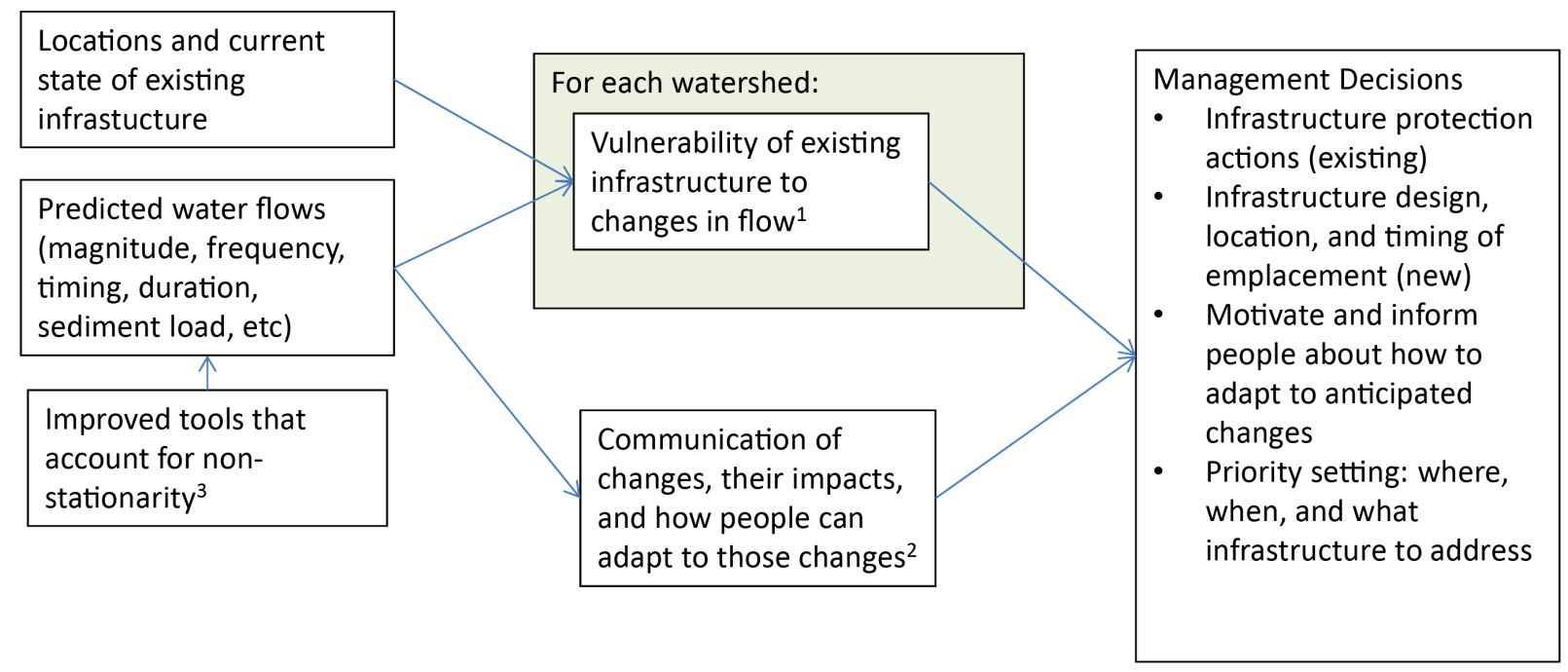

\footnotetext{
${ }^{1}$ Considered especially important to identify local-scale vulnerabilities

2 One important approach to mitigating climate-induced risks to infrastructure is for people to modify their behavior, for example, with respect to buildin g in flood zones, etc. Better communication of potential behavorial changes will increase their effectiveness; how best to communicate the changes, impacts, and mitigation approaches was identified as a potential information need

${ }^{3}$ Particularly useful would be identification of simpler tools and the conditions under which they would provide sufficient information. Examples mentioned include regression equations, IDF curves, updated modeling, and improved model calibration including comparisons of model predictions with streamgage measurements
}

Figure 2.6 Identified key information needs to support decision-making related to protection and management of infrastructure that is subject of changing hydrologic regimes. 
Service, oral commun., 2014). As was the case with aquatic habitats and fisheries, the participants indicated that there was relatively less need for additional information on the effectiveness of specific management actions related to infrastructure protection than for information on vulnerabilities.

This group also discussed the effect of changes in hydrology on agriculture, identifying the most important issue as water availability, both physically and legally. Physical access to water can be addressed in some locations using flow regulation, while legal access is determined by surface-water and groundwater rights and the laws determining how they are maintained or lost. Fundamentally, the information need is for tools to help farmers plan for changes in water availability - for both drought and flood planning. Farmers can respond to forecasts through such decisions as crop choice, including genetically modified crops, tilling methods, soil amendments, and others to mitigate for changes in soil moisture conditions, prevalence of pests and diseases, and other factors (Easterling and others, 1993; Reilly and others, 2003). The importance of the response of soil to hydrologic change (Weltzin and others, 2003) came up relatively late in the workshop and was not the focus of detailed discussion. However, participants noted the importance of soils in determining agricultural practices and observed that soils are only regulated when they cause turbidity and pollution in water.

Protection on the basis of culture importance is afforded Tribal, archaeological, and historical sites. Management decisions regarding protection of these types of sites usually occur in the context of determining dam operations, infrastructure placement, and other resource management operations. Notably, dams can become subject to protection as historical structures at the same time they are tools for affecting other resources.

The participants also identified a need for better information regarding how to effectively communicate future changes to the public (Nisbit, 2010; Kim, 2012). Public understanding of risks and consequences of hydrologic regime shifts, including the concept of non-stationarity (Cooley, 2013), is needed to make better public decisions (for example, zoning regulations, infrastructure placement, federal flood zone maps) and personal decisions about where to live and work, and to anticipate changes in costs such as rates for utilities and flood insurance. Moreover, there are resource use conflicts that can best be resolved by negotiation among wellinformed parties. Specific examples include the conflict between engineered log jams in rivers for fish habitat versus passage for recreational boats; and riparian restoration for habitat and flood control versus an increase in pests as suggested by farmers. Within national parks, there is a need to weigh differing management requirements for natural resources, cultural resources, and visitor facilities, integrating among them when possible. Improved communication methods and tools would facilitate mutual understanding of the effects of climate-related changes in water flows on these resources of interest to multiple parties. Workshop participants were particularly supportive of communication tools in the form of interactive maps.

\section{Tools for Resource Managers}

Workshop participants discussed the watershed as the contextual spatial unit in which decisions are made about where to implement management actions. Therefore, tools for efficiently conducting vulnerability assessments for watersheds are an important need. In general, participants thought it would be useful to focus on the ratio of climate induced change to change that can be addressed by management (Beechie and others, 2013). Specific watershed characteristics and other information listed by the group that would help in understanding the vulnerability of the watershed to climate-related changes in hydrology include connectivity, land 
uses, geology, climate projections, abundance and location of thermal refugia, sediment transport, infrastructure, flood plain conditions, riparian condition, location of redds and other biologically significant features, location of culverts and other infrastructure (for example, buildings, levees, and others), and a measure of biodiversity. The ability to assess watershed vulnerability would be greatly enhanced by a tool that would enable streamlined collection and synthesis of these data, perhaps in checklist format that would be primarily based on extant data. Participants noted that, some data are more available than others. For example, Washington State does not have an adequate database for levees that would help determine where floodplains have been disconnected and where there might be restoration opportunities. Accordingly, some data collection might be required even for a streamlined vulnerability assessment tool.

Once the tool is created, it should be tested in a variety of ways. One option would be to use it in a few watersheds representing rain-dominated, transient, and snow-dominated conditions, or perhaps watersheds with sedimentary versus igneous bedrock geology, or compare watersheds with different ratios of change expected from climate change versus management potential. Another option is to compare results from the evaluation tool based on a subset of the available data versus all data in a data-rich watershed to see whether they indicate the same condition. It also makes sense to conduct vulnerability assessments in areas where damage to resources is urgent. An example is high elevation wetlands that are experiencing climate changedriven changes in depth, hydroperiod, and thermal conditions, and where native organisms also may be threatened by exotic fish stocked for sport fishing (Ryan and others, 2014).

Vulnerability assessments can be used to determine where management actions should be conducted. They also can be used to communicate with the public regarding where the risks are, a justification for the planned response, and how to evaluate the trade-offs among the consequences of public policy. Vulnerability assessment work has been done for the Willamette (Jung and Chang, 2011) and Columbia Rivers (Hamlet and others, 2013), which demonstrates methods and provides examples of leveraging funds to accomplish large-scale assessment projects.

In addition to tools for assessing vulnerability and resilience of watersheds, resource managers would benefit from tools that specifically describe the effects of land-use practices common in urban areas, such as impervious surfaces, wells, and septic systems, on streamflow. The most powerful tools presently (2014) available to meet this need are Hydrological Simulation Model-Fortran models. These models simulate hydrologic and associated waterquality processes on pervious and impervious land surfaces and in streams and well-mixed impoundments (Bicknell and others, 1997), but they are very complex and difficult to apply. Perhaps a tool could be developed for watersheds based on global information system layers describing impervious surfaces, wells, and other hydrologically related structures. The Washington State Department of Ecology has such a tool for application to shorelines that may be adaptable to streams.

\section{Summary}

There were numerous commonalities in the key information needs identified for each set of valued resources, as well as a few unique needs. Figure 2.7 represents a consolidation and summary of the needs identified in figures 2.4-2.6. In general, workshop participants identified several fundamental data gaps regarding hydrology and three categories of tools needed by resource managers to make the decisions appropriate for managing wetlands, riparian areas, infrastructure, and fisheries: (1) comprehensive vulnerability assessments of watersheds, (2) 
estimates of the effectiveness of potential actions to create the desired change, and (3) tools for communicating with and engaging the public. These are summarized in Table 2.2. Completing watershed assessments has additional information requirements for projections of the effects of climate change on streamflow, water quality, and habitat complexity as well as the location of infrastructure and resilient stream reaches. Making projections regarding the effects of climate change requires fundamental scientific understanding of the role of groundwater in hydrologic systems and the need to incorporate non-stationarity into projection of flows. This simplified list, background regarding the complexities of topics, and linkage of information needs to management decisions developed during this workshop will provide a firm foundation for NPLCC staff to prioritize needs and develop funding calls to address the effects of hydrologic regime shifts on rivers, streams, and riparian corridors.

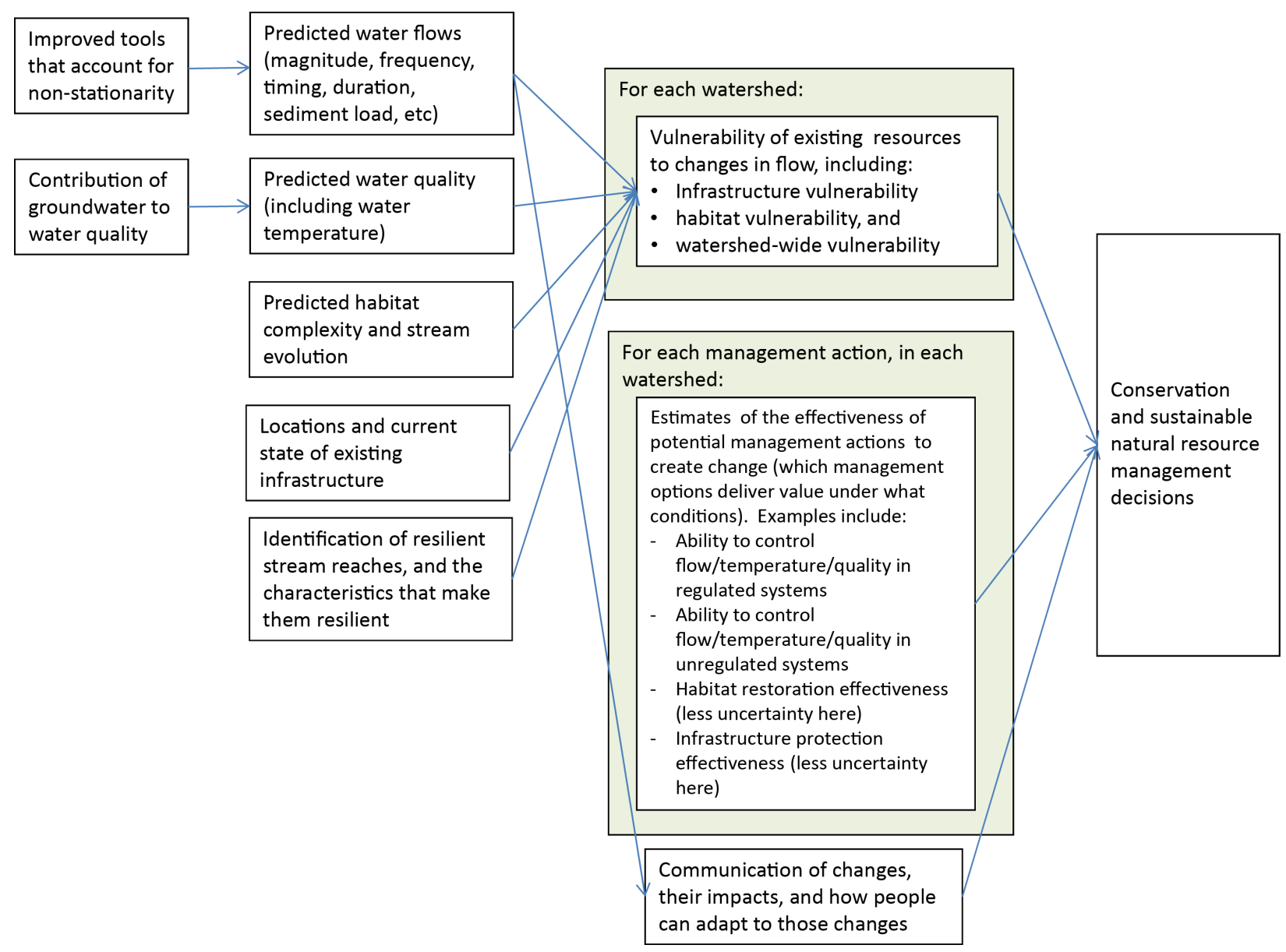

Figure 2.7 Identified key information needs to support conservation and sustainable natural resource management decision about resources affected by climate-induced changes in hydrologic regimes. 
Table 2.2 Data and tools that would be useful to meet information needs.

[Abbreviations: LiDAR, Light Detection and Ranging; FLIR, forward looking infrared]

\begin{tabular}{|c|c|c|}
\hline Information need & $\begin{array}{c}\text { Useful data and tools (some } \\
\text { available, some not yet available) }\end{array}$ & Additional discussion items \\
\hline $\begin{array}{l}\text { Predicted water flows (magnitude, } \\
\text { frequency, timing, duration, } \\
\text { sediment load, etc.) }\end{array}$ & $\begin{array}{l}\text { Data: } \\
\text { - for example, LiDAR, snowpack, } \\
\text { flow, precipitation, land use, } \\
\text { local knowledge, repetitive cross } \\
\text { sections, FLIR } \\
\text { Models: } \\
\text { - Note need to consider questions } \\
\text { related to model calibration: } \\
\text { comparison of stream gauge } \\
\text { measurements with model } \\
\text { projections } \\
\text { Tools: } \\
\text { for example, regression } \\
\text { equations, IDF curves. Simpler } \\
\text { tools are preferred, but need an } \\
\text { understanding of when they } \\
\text { provide sufficient information }\end{array}$ & $\begin{array}{l}\text { Critical gaps include: } \\
\text { - } \quad \text { Data / information for non- } \\
\text { gaged streams } \\
\text { - } \quad \text { Data / information for rain- } \\
\text { dominated systems } \\
\text { - } \quad \text { Fine-scaled data }\end{array}$ \\
\hline $\begin{array}{l}\text { Contribution of groundwater to } \\
\text { water quality }\end{array}$ & $\begin{array}{ll}\text { - } & \text { Seepage runs } \\
\text { - } & \text { Well monitoring results } \\
\text { - } & \text { Stream gauge analyses } \\
\text { - } & \text { Measurement of other water } \\
\text { quality parameters } \\
\text { - } \\
\text { dse of FLIR and temperature } \\
\text { data to find locations of } \\
\text { groundwater - surface water } \\
\text { connections } \\
\text { Geologic mapping }\end{array}$ & $\begin{array}{l}\text { Where to conduct these studies } \\
\text { (applies to more than just } \\
\text { groundwater)? } \\
\text { - Connect to vulnerability } \\
\text { assessments; focus in watersheds } \\
\text { that are of interest from the } \\
\text { vulnerability perspective } \\
\text { - Small number of index sites over } \\
10 \text { years - use to create a } \\
\text { framework/template that can be } \\
\text { applied in other watersheds }\end{array}$ \\
\hline Watershed-wide vulnerability & 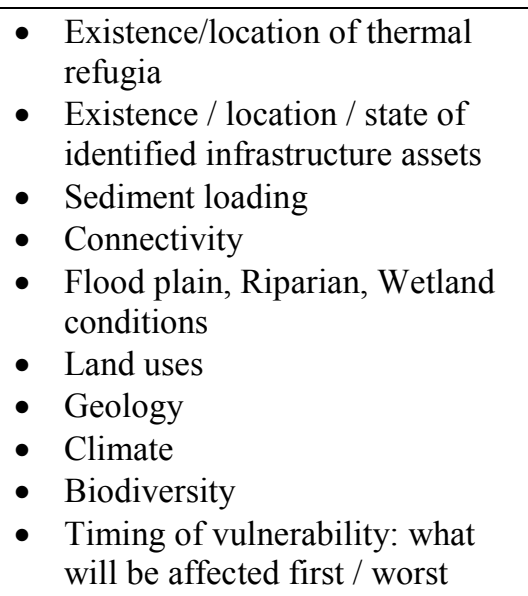 & $\begin{array}{l}\text { How to select one or a few } \\
\text { watersheds to do the initial } \\
\text { development of the framework? } \\
\text { (consider the "index watershed" } \\
\text { approach with longer-term } \\
\text { monitoring) } \\
\text { - Select an initial "portfolio" of } \\
\text { representative watersheds that } \\
\text { differ from each other } \\
\text { - Management } \\
\text { - Geologic } \\
\text { - Find a watershed that is about to } \\
\text { do work }\end{array}$ \\
\hline $\begin{array}{l}\text { Actions available, and their } \\
\text { effectiveness at created change } \\
\text { (which management actions deliver } \\
\text { value under what conditions) }\end{array}$ & $\begin{array}{l}\text { Regulated systems: } \\
\text { - Assess dam capacity and } \\
\text { operating parameters to } \\
\text { understand management }\end{array}$ & \\
\hline
\end{tabular}




\begin{tabular}{|c|c|c|}
\hline Information need & $\begin{array}{l}\text { Useful data and tools (some } \\
\text { available, some not yet available) }\end{array}$ & Additional discussion items \\
\hline & $\begin{array}{l}\text { capacity (may be lots of } \\
\text { information? Know less } \\
\text { about systems that are } \\
\text { managed for irrigation) } \\
\text { Consider operating } \\
\text { mandates and feasibility of } \\
\text { making changes } \\
\text { Unregulated systems: } \\
\text { Effect of land use on flow } \\
\text { - look at several } \\
\text { watersheds with very } \\
\text { different land uses; } \\
\text { "Historic" study of the } \\
\text { effects of previously - } \\
\text { conducted restoration } \\
\text { projects } \\
\text { Experimental approach - } \\
\text { with short and long-term } \\
\text { monitoring of the results of } \\
\text { different management } \\
\text { approaches }\end{array}$ & \\
\hline
\end{tabular}

\section{Acknowledgments}

The authors greatly appreciate the enthusiastic discussion and breadth of ideas provided by meeting participants. We also thank Jason Dunham and one anonymous reviewer for improvements to the draft manuscript.

\section{References Cited}

Abatzoglou, J.T., Rupp, D.E., and Mote, P.W., 2013, Seasonal climate variability and change in the Pacific Northwest of the United States: Journal of Climate, v. 27, p. 2,125-2,142.

Arismendi, I., Johnson, S.L., Dunham, J.B., Haggerty, R., and Hockman-Wert, D., 2012, The paradox of cooling streams in a warming world-Regional climate trends do not parallel variable local trends in stream temperature in the Pacific continental United States: Geophysical Research Letters, v. 39, L10401.

Arismendi, I., Safeeq, M., Dunham, J., and Johnson, S.L., in press, Can air temperature be used to project influences of climate change on stream temperature?: Environmental Research Letters.

Barnett, T.P., Adam, J.C., and Lettenmaier, D.P., 2005, Potential impacts of a warming climate on water availability in snow-dominated regions: Nature, v. 438, p., 303-309.

Beechie, T., Imaki, H., Greene, J., Wade, A., Wu, H., Pess, G., Roni, P., Kimball, J., Stanford, J., Kiffney, P., and Mantua, N., 2013, Restoring salmon habitat for a changing climate: River Research and Applications, v. 29, p. 939-960. 
Beechie, T.J., Pess, G., Beamer, E., Lucchetti, G., and Bilby, R.E., 2003, Role of watershed assessments in recovery planning for endangered salmon in Montgomery, D., Bolton, S., Booth, D., and Wall, L., eds., Restoration of Puget Sound rivers: Seattle, University of Washington Press, p. 194-225.

Bellmore, J.R., Baxter, C.V., Connolly, P.J., and Martens, K., 2013, The floodplain food web mosaic: a study of its importance to salmon and steelhead with implications for their recovery: Ecological Applications, v. 23, p. 189-207.

Bicknell, B.R., Imhoff, J.C., Kittle, J.L., Jr., Donigian, A.S., Jr., and Johanson, R.C., 1997, Hydrological Simulation Program-Fortran, user's manual for version 11: U.S. Environmental Protection Agency, National Exposure Research Laboratory, Athens, Ga., EPA/600/R-97/080, $755 \mathrm{p}$.

Bureau of Land Management, 1998, Riparian area management, process for assessing proper functioning condition: Bureau of Land Management, Technical Reference 1737-9.

Chang, H., and Jong, I.-W., 2010, Spatial and temporal changes in runoff caused by climate change in a complex large river basin in Oregon: Journal of Hydrology, v. 388, p. 186-207.

Cluer, B., and Thorne, C., 2014, A stream evolution model integrating habitat and ecosystem benefits: River Research and Applications, v. 30, p. 135-154.

Chang, H., Jung, I.-W., Steele, M., and Gannett, M., 2012, Spatial patterns of March and September streamflow trends in Pacific Northwest streams, 1958-2008: Geographical Analysis, v. 44, p. 177-201.

Comte, L., and Grenouillet, G., 2013, Do stream fish track climate change?-Assessing distribution shifts in recent decades: Ecography, v. 36, p. 1,236-1,246.

Cooley, D., 2013, Return periods and return levels under climate change, in AghaKouchak, A., Easterling, D., Hsu, K., Schubert, S. and Sorooshian, S., eds., Extremes in a changing climate: Dordrecht, Netherlands, Springer, Detection, Analysis and Uncertainty, Springer, 423 p.

Diabat, M., Haggerty, R., and Wondzell, S.M., 2012, Diurnal timing of warmer air under climate change affects magnitude, timing, and duration of stream temperature change: Hydrological Processes, v. 27, p. 2,367-2,378.

Durrans, S.R., 2010, Intensity-duration-frequency curves, in Testik, F.Y., and Gebremichael, Mekonnen, eds., Rainfall—State of the Science: Geophysical Monograph Series 191, p. 159171.

Easterling, W.E., Crosson, P.R., Rosenberg, N.J., McKenney, M.S., Katz, L.A., and Lemon, K.M., 1993, Paper 2, Agricultural impacts of and responses to climate change in the MissouriIowa-Nebraska-Kansas (MINK) region: Climatic Change, v. 24, p. 23-61.

Eby, L.A., Helmy, O., Holsinger, L.M., and Young, M.K., 2014, Evidence of climate-induced range contractions in bull trout, Salvelinus confluentus, in a Rocky Mountain watershed, U.S.A.: PLoS ONE, v. 9, p. e98812.

Franklin, J.F., and Dyrness, C.T., 1973, Natural vegetation of Oregon and Washington: Corvallis, Oregon State University Press,.

Grant, G.E., Lewis, S.L., Swanson, F.J, Cissel, J.H., and McDonnell, J.J., 2008, Effects of forest practices on peak flows and consequent channel response-A state of the science report for western Oregon and Washington: U.S. Forest Service, PNW-GTR-760.

Hamlet, A.F., Elsner, M.M., Mauger, G.S., Lee, S.-Y., Tohver, I., and Norheim, R.A., 2013, An overview of the Columbia Basin climate change scenarios project-Approach, methods, and summary of key results: Atmosphere-Ocean, v. 51, p. 392-1,246. 
Hamlet, A.F., and Lettenmaier, D.P., 1999, Effects of climate change on hydrology and water resources in the Columbia River Basin: Journal of the American Water Resources Association, v. 35, P. 1,597-1,623.

Howard, R.A., and Matheson, J.E., 2005, Influence diagrams: Decision analysis, v. 2, p. 127143.

Isaak, D.J., Wollrab, S., Horan, D., and Chandler, G., 2012, Climate change effects on stream and river temperatures across the northwest U.S. from 1980-2009 and implications for salmonid fishes: Climatic Change, v. 113, p. 499-524.

Jenni, K., Shipley, F., and Mahaffy, M., 2012, Strategy for science-traditional ecological knowledge, 2013-2016 (Version 1.0): Lacey, Washington, North Pacific Landscape Conservation Cooperative, 19 p., accessed September 8, 2013, at http://northpacificlcc.org/Documents/S-TEK\%20Strategy_Final_11-2012.pdf.

Jung, I.W., and Chang, H., 2011, Assessment of future runoff trends under multiple climate change scenarios in the Willamette River basin, Oregon, USA: Hydrological Processes, v. 25, p. 258-277.

Keefer, D.L., Kirkwood, C.W., and Corner, J.L., 2004, Perspective on decision analysis applications, 1990-2001: Decision Analysis, v. 1, p. 5-24.

Kim, H.-S., 2012, Climate change, science, and community: Public Understanding of Science, v. 21, p. 268-285.

Kundzewicz, Z.W., Mata, L.J., Arnell, N.W., Doll, P., Jimenez, B., Miller, K., Oki, T., Sen, Z., and Shiklomanov, I., 2008, The implications of projected climate change for freshwater resources and their management: Hydrological Resources Journal, v. 53, p. 3-10.

Lawrence, D.J., Stewart-Koster, B., Olden, J.D., Ruesch, A.S., Torgersen, C.E., Lawler, J.J., 2014, The interactive effects of climate change, riparian management, and a non-native predators on stream-rearing salmon: Ecological Applications, v. 24, no. 4, p. 895-912.

Leung, L.R., and Qian, Y., 2009, Atmospheric rivers induced heavy precipitation and flooding in the western U.S. simulated by the WRF regional climate model: Geophysical Letters, v. 36, p. L03820.

Littell, J.S., Oneil, E.E., McKenzie, D., Hicke, J.A., Lutz, A.A., Norheim, R.A., and Elsner, M.M., 2010, Forest ecosystems, disturbance and climatic change in Washington State, USA: Climatic Change, v. 102, p. 129-158.

Loukas, A., Vasiliades, L., and Dalezious, N.R., 2000, Flood producing mechanisms identification in southern British Columbia, Canada: Journal of Hydrology, v. 227, p. 218-235.

Mantua, N.J., Tohver, I., and Hamlet, A., 2010, Climate change impacts on streamflow extremes and summertime stream temperature and their possible consequences for freshwater salmon habitat in Washington State: Climatic Change, v. 102, p., 187-223.

Marchetti, M.P., and Moyle, P.B., 2001, Effects of flow regime on fish assemblages in a regulated California stream: Ecological Applications, v. 11, p. 530-539.

McCabe, G.J., Hay, L.E., and Clark, M.P., 2007, Rain-on-snow events in the western United States: Bulletin of the American Meteorological Society, v. 88, p. 319-328.

Merz, R., Parajka, J., and Bloschl, G., 2011, Time stability of catchment model parameters: implications for climate impact analyses: Water Resources Research, v. 47, p. W02531.

Miles, E.L., Snover, A.K., Hamlet, A.K., Callahan, B., and Fluharty, D., 2000, Pacific Northwest regional assessment - The impacts of climate variability and climate change on the water resources of the Columbia River basin: Journal of the American Water Resources Association, v. 36, p. 399-420. 
Miller, D., Luce, C., and Benda, L., 2003, Time, space and episodicity of physical disturbance in streams: Forest Ecology and Management, v. 178, p. 121-140.

Mote, P.W., Parson, E.A., Hamlet, A.F., Keeton, W.S., Lettenmaier, D., Mantua, N, Miles, E.L., Peterson, D.W., Peterson, D.L., Slaughter, P., and Snover, A.K., 2003, Preparing for climatic change-The water, salmon, and forests of the Pacific Northwest: Climatic Change, v. 61, p. 45-88.

Nesbit, M.C., 2010, Communicating climate change-Why frames matter for public engagement: Environment-Science and Policy for Sustainable Development, v. 51, p. 12-23.

Nieman, P.J., Ralph, F.M., Wick, G.A., Lundquist, J.D., and Dettinger, M.D., 2008, Meteorologic characteristics and overland precipitation impacts of atmospheric rivers affecting the west coast of North America based on 8 years of SSM/I satellite observations: Journal of Hydrometeorology, v. 9, p. 22-47.

North Pacific Landscape Conservation Cooperative, undated, North pacific landscape conservation cooperative charter, http://northpacificlcc.org/NPLCC_Charter.pdf.

Palmer, M.A., Reidy Liermann, C.A., Nilsson, C., Florke, M., Alcamo, J., Lake, P.S., and Bond, N., 2008, Climate change and the world's river basins-Anticipating Management Options, v. 6, p. 81-89.

Pearl, J., 2005, Influence diagrams-Historical and personal perspectives: Decision Analysis, v. 2, p. 232-234.

Reeves, G.H., Bende, L.E., Burnett, K.M., Bisson, P.A., and Sedell, J.R., 1995, A disturbancebased ecosystem approach to maintaining and restoring freshwater habitats of evolutionarily significant units of anadromous salmonids in the Pacific Northwest: American Fisheries Society Symposium, v. 17, p. 334-349.

Reilly, J., Tubiello, F., McCarl, B., Abler, D., Darwin, R., Fuglie, K., Hollinger, S., Izaurralde, C., Jagtap, S., Jones, J., Mearns, L., Ojima, D., Paul, E., Paustian, K., Riha, S., Rosenberg, N., and Rosenzweig, C., 2003, U.S. agriculture and climate change-New results: Climatic Change, v. 57, p. 43-69.

Rich, C.F., McMahon, T.E., Rieman, B.E., and Thompson, W.L., 2003, Local-habitat, watershed, and biotic features associated with bull trout occurrence in Montana streams: Transactions of the American Fisheries Society, v. 132, p. 1,053-1,064.

Roni, P., Beechie, T.J., Bilby, R.E., Leonetti, F.E., Pollock, M.M., and Pess, G.R., 2002, A review of stream restoration techniques and a hierarchical strategy for prioritizing restoration in Pacific Northwest watersheds: North American Journal of Fisheries Management, v. 22, p. $1-20$.

Ryan, M.E., Palen, W.J., Adams, M.J., and Rochefort, R.M., 2014, Amphibians in the climate vice-Loss and restoration of resilience of montane wetland ecosystems in the western US: Frontiers in Ecology and the Environment, v.12, p. 232-240.

Stewart, I.T., Cayan, D.R., and Dettinger, M.D., 2005, Changes toward earlier streamflow timing across western North America: Journal of Climate, v. 18, p. 1,136-1,155.

Tague, C., and Grant, G.E., 2004, A geological framework for interpreting the low flow regimes of Cascade streams, Willamette River Basin, Oregon: Water Resources Research, v. 40, p. W04303.

Tague, G., Grant, G., Farrell, M., Choate, J., and Jefferson, A., 2008, Deep groundwater mediates streamflow response to climate warming in the Oregon Cascades: Climatic Changes, v. 86, p. 189-210. 
Tohver, I.M., Hamlet, A.F., and Lee, S.-Y., 2014, Impacts of 21st-century climate change on hydrologic extremes in the Pacific Northwest region of North America: Journal of the American Water Resources Association, p. 1-16, DOI:10.1111/jawr.12199.

Waples, R.S., Beechie, T., and Pess, G.R., 2009, Evolutionary history, habitat disturbance regimes, and anthropogenic change-What do these mean for resilience of Pacific salmon populations?: Ecology and Society, v. 14, article 3.

Waples, R.S., Pess, G.R., and Beechie, T., 2008, Evolutionary history of Pacific salmon in dynamic environments: Evolutionary Applications, v. 1, p. 189-206.

Weltzin, J.F., Loik, M.E., Schwinning, S., Williams, D.G., Fay, P.A., Haddad, B.M., Harte, J., Huxman, T.E., Knapp, A.K., Lin, G., Pickman, W.T., Shaw, R.M., Small, E.E., Smith, M.D., Smith, S.D., Tissue, D.T., and Zak, J.C., 2003, Assessing the response of terrestrial ecosystem to potential change in precipitation: BioScience, v. 53, p. 941-952.

Whitehead, R.L., 1994, Groundwater atlas of the United States, Segment 7, Idaho, Washington, Oregon: U.S. Geological Survey Hydrologic Investigations Atlas 730-H.

Woodward, A., Liedtke, T., and Jenni, K., 2014, Identifying resource manager information needs for the North Pacific Landscape Conservation Cooperative: U.S. Geological Survey Open-File Report 2014-1032, 54 p.

Yousef, L.A., and Ouarda, T., 2013, Formulation of intensity-duration-frequency curves incorporating non-stationarity: American Geophysical Union, abstract \#ED31F-07.

Ziemer, R.R., 1998, Proceedings of the conference on coastal watersheds-The Caspar Creek story: U.S. Forest Service, PSW-GTR-168. 


\section{Appendix A. Hydrology Workshop Participants}

\begin{tabular}{|l|l|}
\hline \multicolumn{1}{|c|}{ Name } & \multicolumn{1}{c|}{ Affiliation } \\
\hline Paul Bakke & U.S. Fish and Wildlife Service, Washington Fish and Wildlife Office \\
\hline Gustavo Bisbal & U.S. Geological Survey, Northwest Climate Science Center \\
\hline Janine Castro & $\begin{array}{l}\text { U.S. Fish and Wildlife Service, Oregon Fish and Wildlife Office, National } \\
\text { Oceanic and Atmospheric Administration National Marine Fisheries } \\
\text { Service }\end{array}$ \\
\hline Bruce Duffe & U.S. Army Corps of Engineers \\
\hline Keith Duffy & U.S. Army Corps of Engineers \\
\hline Gordon Grant & $\begin{array}{l}\text { U.S. Department of Agriculture, Forest Service Pacific Northwest } \\
\text { Research Station; Oregon State University }\end{array}$ \\
\hline David Graves & Columbia River Intertribal Fish Council \\
\hline Karen Jenni & Insight Decisions, LLC \\
\hline Casey Kramer & Washington State Department of Transportation \\
\hline Nick Legg & Washington State Department of Ecology \\
\hline Mary Mahaffy & North Pacific Landscape Conservation Cooperative \\
\hline Tim Mayer & U.S. Fish and Wildlife Service, Pacific Region Water Resources Branch \\
\hline Patricia Olson & Washington State Department of Ecology \\
\hline Paul Pickett & Washington State Department of Ecology \\
\hline Jonathan Soll & Oregon Metro \\
\hline Julie Vano & Oregon Climate Change Research Institute \\
\hline Meghan Walter & Natural Resource Conservation Service \\
\hline Andrea Woodward & $\begin{array}{l}\text { U.S. Geological Survey - Forest and Rangeland Ecosystem Science } \\
\text { Center }\end{array}$ \\
\hline
\end{tabular}




\section{Appendix B. Hydrology Workshop Agenda}

\section{Effects of Climate-Related Hydrologic Changes on Natural Resources of the North Pacific Landscape Conservation Cooperative (NPLCC) \\ January 23, 2014}

Focal Geography: Snoqualmie Pass to Klamath Mountains; Cascade crest to Pacific Ocean

Workshop Goals:

1) Develop list of resources expected to be affected by changes in hydrology.

2) Consider how priority resources will be affected.

3) Identify potential management actions and decisions that could be used to prevent or mitigate hydrologyrelated effects.

4) Identify and prioritize information needs that will affect the ability of managers to enact decisions or take actions.

5) Summarize the group discussions in a conceptual framework that clarifies linkages.

8:30-9:00 am Coffee and pastries

9:00 - 9:30 am Introductions to each other, to NPLCC, and to meeting goals and process

9:30 - 10:30 am Conceptual Model I: Review elements of conceptual model of climate change impacts to hydrology (based on webinar from previous week)

- Valued Resources

- Management Goals

$10: 30-10: 40$ am Break

10:40 - 11:15 am Conceptual Model II: Continue reviewing conceptual model with focus on:

- Management Actions

- Management Decisions

11:15 - 11:30 Prioritize topics for break-out groups and describe desired outcome

11:30 am - 12:00 pm Pick up lunch in cafeteria

12:00 - 1:45 pm Break-out groups: Identify information needed to support management decisions (working lunch)

$1: 45-2: 30 \mathrm{pm} \quad$ Group reports

2:30-2:45 pm Break

2:45 - 4:45 pm Comprehensive evaluation of information needs

- Are there commonalities across topics?

- What information needs have already have sufficient information to support decision making? Partial information?

- For un-met information needs, what approaches and which entities are best suited to address each need? (e.g., field studies by academics; meta-analysis by the NPLCC; etc.)

- What information needs can be uniquely met by the NPLCC?

- Make recommendations for information priorities

4:45 - 5:00 pm Summarize and conclude meeting 
Publishing support provided by the U.S. Geological Survey Science Publishing Network, Tacoma Publishing Service Center

For more information concerning the research in this report, contact the Director, Forest and Rangeland Ecosystem Science Center U.S. Geological Survey

777 NW 9th Street, Suite 400

Corvallis, Oregon 97330

http://fresc.usgs.gov 


\section{हू}

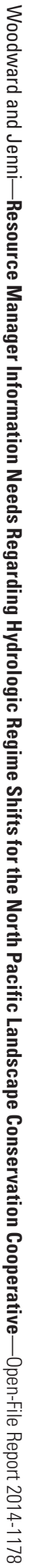

